\title{
EFEKTIVITAS DIPPING BIJI DAN KULIT ANGGUR HITAM PADA KUALITAS AIR SUSU SAPI PERAH TROPIS
}

\author{
Dyanovita Al Kurnia ${ }^{1)}$ and Qabilah Cita K. N. S ${ }^{2)}$ \\ 1) Program Studi Peternakan Fakultas Peternakan Universitas Islam Lamongan \\ 2) Fakultas Peternakan Universitas Islam Lamongan. \\ Jl.Veteran No.53.A Lamongan
}

\begin{abstract}
ABSTRAK
Tujuan penelitian ini adalah untuk menguji potensi penggunaan dipping (biji dan kulit buah anggur hitam) pada kualitas air susu sapi perah tropis ditinjau dalam mengurangi kontaminasi bakteri susu dan mastitis sapi perah jika dibandingkan dengan dipping sintetis. Bahan yang digunakan dalam penelitian ini adalah 12 ekor sapi perah yang berumur 3-4 laktasi. Dipping terdiri dari 50\% biji: 50\% kulit anggur hitam yang digiling menjadi tepung sebelumnya. Kemudian ekstraksi dengan aquadesh pada beberapa level adalah $\mathrm{p} 0=$ dicelup sintetis, $\mathrm{P} 1=20 \%$ campuran tepung biji dan kulit anggur hitam, P2 $=50 \%$ campuran tepung biji dan kulit anggur hitam, P3 $=80 \%$ campuran tepung biji dan kulit anggur hitam. Sapi perah dibagi menjadi empat tingkat perawatan pencelupan secara acak menjadi $0 \%, 20 \%$ $50 \%, 80 \%$. Tiga ulangan masing-masing. Variabel yang diamati adalah mengurangi kontaminasi bakteri dan mastitis sapi perah. Data dianalisis dengan menggunakan Rancangan Acak Lengkap, ketika ada pengaruh signifikan yang diikuti oleh Uji Jarak Berganda Duncan. Hasil penelitian menunjukkan bahwa penggunaan celupan bikang (biji dan kulit buah anggur hitam) untuk mengurangi kontaminasi bakteri susu dan mastitis sapi perah tidak berbeda nyata $(P>0,05)$. Ini berarti bahwa potensi perlakuan campuran biji dan kulit anggur hitam sama dengan mencelupkan dengan dipping sintetik dalam mengurangi kontaminasi bakteri susu dan mastitis. Kesimpulan penelitian ini adalah potensi perlakuan biji dan campuran kulit yang sama dengan mencelupkan sintetis dalam mengurangi kontaminasi bakteri susu dan mastitis. Tingkat pengobatan yang optimal menggunakan pencelupan bikang adalah $80 \%$ campuran tepung biji dan kulit anggur hitam dengan $200 \mathrm{ml}$ aquades.
\end{abstract}

Kata Kunci: Dipping, Biji, Kulit, Anggur hitam, Air Susu, Sapi Perah.

\section{PENDAHULUAN}

Rendahnya produksi susu dalam negeri diakibatkan oleh banyak hal, baik karena populasi sapi perah yang hanya berkisar 600 ribu ekor, ataupun karena kemampuan produksi susu rata-rata seekor sapi perah yaitu dibawah 10 liter per ekor per hari. Selain itu peternakan sapi perah secara nasional banyak dimiliki oleh peternak rakyat dengan skala produksi dan manjemen yang masih tradisional. Manajemen sapi perah oleh peternak rakyat seringkali tidak megindahkan tata laksana pemeliharaan yang baik.

Hasil penelitian secara intensif yang dilakukan di beberapa peternakan di daerah pengembangan ternak perah seperti Jawa Barat, Jawa Tengah dan Jawa Timur prevalensi mastitis sub klinis berkisar antara 37 sampai $67 \%$ dan mastitis klinis antara 5 sampai 30\% (Setiadi,2009).

$S$. aerus merupakan salah satu pathogen yang paling sering menyebabkan infeksi dan tidak memberikan respon terhadap kebanyakan antibiotika. Staphylococcus aerus adalah mengakibatkan infeksi pada jaringan tubuh. Penyakit yang muncul akibat infeksi. Staphylococcus aerus dapat menimbulkan tingkat keseriusan yang parah dan dapat merusak antibody tubuh dan apabila mencemari air susu dalam jumlah yang besar dapat menimbulkan efek keracunan.

Prasetyanti (2016) menyatakan bahwa mastitis yang disebabkan bakteri Staphylococcus aerus dapat menimbulkan cemaran air susu dimana kualitas susu merupakan faktor utama bagi konsumen. Menurut Standar Nasional Indonesia (SNI) 01 3141-2011 batas maksimum bakteri dalam susu adalah $1,0 \times 10^{6} \mathrm{CFU} / \mathrm{ml}$. Sementara karena banyaknya kejadian mastitis di Indonesia menyebabkan susu segar dari peternak rakyat sering ditolak Industri Pengolah Susu karena nilai batas maksimum bakteri dalam air susu yang melebihi standart SNI.

Ekstrak biji dan kulit anggur diketahui dapat membunuh hingga 800 strain yang 
berbeda dari virus dan bakteri. Ekstrak biji dan kulit ini pun mampu membersihkan bakteribakteri dalam tubuh karena bersifat antibakteri dan mampu mengurangi kontaminasi bakteri dalam makanan. (Paulo et al, 2011). Biji dan kulit anggur apabila diekstrak mengeluarkan senyawa aktif seperti resveratrol yang mampu membunuh bakteri Stapylococcus aerus. Ekstrak biji anggur memiliki kandungan senyawa kimia didalamnya sebagai anti inflamasi dan anti bakteri. (Roh et al, 2014).

Resveratrol yang terdapat pada buah anggur dapat meningkatkan aliran darah pada otak, sehingga dapat mereduksi dan mencegah penyakit bekerja dengan menghambat senyawa benzopyrene, yaitu senyawa yang dapat menyebabkan kanker, serta menghambat pertumbuhan sel abnormal (Xia et al, 2010).

Kandungan tanin sebesar $5.2 \%$ pada kulit dan biji anggur (Eleonora, et al. 2014) menyebabkan adanya rasa pahit apabila dikonsumsi ternak. Sehingga kulit dan biji anggur diaplikasikan pemanfaatnya sebagai dipping. Cara kerja dipping adalah mencegah jumlah bakteri yang masuk kedalam putting sapi perah saat pemerahan dengan mencelup putting ke dalam larutan desinfektan sebagai dipping selama 4 menit. Namun pemanfaatan desinfektan kimia dirasa tidak aman karena residu kimia yang ikut masuk dalam air susu hasil pemerahan sebagai faktor penyebab cemaran air susu.

Residu kimia yang terbawa pada produk pangan asal ternak apabila dikonsumsi manusia sering kali menjadi penyebab alergi, ataupun penyakit lainnya. Oleh karena itu diperlukan terobosan baru dengan menggunakan produk dipping yang berbahan dasar limbah dari tanaman yang tumbuh baik di Indonesia yaitu anggur. Sehingga pemanfaatannya dapat memberi dampak yang positif bagi berbagai pihak karena berbahan dasar dari limbah.

Oleh karena itu penting dilakukan penelitian dengan judul "Potensi dipping bikang (biji dan kulit anggur hitam) dalam menurunkan bakteri cemaran air susu dan mastitis sapi perah"

Metode yang digunakan dalam penelitian ini adalah Rancangan Acak Lengkap dengan 4 perlakuan dimana masing-masing perlakuan menggunakan 3 ulangan sapi perah. Perlakuan yang dilakukan adalah sebagai berikut :

P0 = dipping sintetis / antiseptic kimia
P1 = dipping dengan ekstrak biji dan kulit anggur $20 \%$

P2 = dipping dengan ekstrak biji dan kulit anggur $50 \%$

P3 = dipping dengan ekstrak biji dan kulitanggur $80 \%$

Perlakuan dipping pada penelitian selama 28 hari. Pengambilan data uji CMT dilakukan pada hari ke-0, ke-7, ke-14, ke-21 dan ke-29 hari. Sementara sampel uji bakteri dilakukan pada saat hari ke-0 dan setelah hari ke-29.

Pengujian CMT dilakukan sebelum susu diperah pada pagi hari. Langkah pengujian CMT yang pertama adalah putting dibersihkan dengan alcohol. Uji California Mastitis Test (CMT) ditentukan dengan cara mereaksikan $2 \mathrm{ml}$ susu dengan $2 \mathrm{ml}$ reagen CMT yang mengandung arylsulfonate di dalam paddel. Campuran tersebut digoyang-goyang membentuk lingkaran horizontal selama 10 detik. Reaksi ini ditandai dengan ada tidaknya perubahan pada kekentalan susu, kemudian ditentukan berdasarkan skoring California Mastitis Test (CMT) yaitu (-) tidak ada pengendapan pada susu, $(+)$ terdapat sedikit pengendapan pada susu, (++) terdapat pengendapan yang jelas namun jel belum terbentuk, $(+++)$ campuran menebaldan mulai terbentuk jel, serta $(++++)$ jel yang terbentuk menyebabkan permukaan menjadi cembung, untuk memudahkan perhitungan statistik maka lambang-lambang tersebut diberi nilai masingmasing, untuk lambang (-) nilainya $0,(+)$ nilainya $1,(++)$ nilainya $2,(+++)$ nilainya 3 dan $(+++)$ nilainya 4 untuk tiap puting susu (Andriani, 2010).

California Mastitis Tes / CMT merupakan salah satu metode diagnosa mastitis subklinis yang sampai saat ini dianggap sederhana dan cepat yaitu metode dengan menggunakan alat yang disebut paddle dan menggunakan reagen untuk mengetahui tingkat keparahan mastitis subklinis yang dialami. (Julianto, 2011).

Metode perhitungan jumlah bakteri yang umum digunakan adalah metode hitungan cawan yang didasarkan pada anggapan bahwa setiap sel yang dapat hidup akan berkembang menjadi satu koloni sehingga jumlah koloni yang muncul pada cawan merupakan satu indeks bagi jumlah organism yang dapat hidup yang terkandung dalam sampel. Memenuhi persyaratan statistik, cawan yang dipilih untuk perhitungan koloni 
ialah yang mengandung antara 25 -250 atau $30-300$ koloni. Karena jumlah mikroorganisme dalam sampel tidak diketahui sebelumnya maka untuk memperoleh sekurang-kurangnya satu cawan yang mengandung koloni dalam jumlah yang memenuhi syarat tersebut maka dilakukan pengenceran.

Jumlah mikroorganisme yang terdapat dalam sampel asal ditentukan dengan mengalikan jumlah koloni yang terbentuk dengan faktor pengenceran pada cawan yang bersangkutan. Metode hitung cawan merupakan metode yang paling sensitif untuk menghitung jumlah mikroorganisme. Untuk menghitung jumlah bakteri yang terdapat pada cawan, digunakan rumus sebagai berikut (Fardiaz,1993).

Jumlah Bakteri/ml sampel= Koloni/cawan $x$ 1/faktor pengencer Perhitungan jumlah mikrobia menggunakan metode hitungan cawan tuang atau pour plate count (Fardiaz, 1993). Sebanyak $10 \mathrm{ml}$ sampel susu dimasukkan kedalam labu Erlenmeyer berisi $90 \mathrm{ml}$ air steril (pengenceran 10), kemudian diencerkan secara seri. Suspensi sebanyak $1 \mathrm{ml}$ dari seri pengenceran yang sesuai dipipet dengan menggunakan pipet steril dan diletakkan pada cawan petri steril kemudian dituangi medium agar (NA) steril sebanyak $12-15 \mathrm{ml}$ yang bersuhu $50-55^{\circ} \mathrm{C}$. Setelah selesai, semua cawan petri diberi pelabelan dan diisolasi pada bagian mulut cawan.Kemudian cawan-cawan petri tersebut dimasukkan ke dalam plastik steril. Plastik dapat disterilkan dengan cara disemprotkan alkohol $70 \%$ bagian dalamnya. Semua cawan petri diinkubasi dalam inkubator selama 24 jam, selanjutnya dihitung jumlah koloni mikrobia yang terdapat pada cawan dengan ketentuan jumlah koloni yang dihitung jumlahnya antara 25 -250.Jumlah koloni yang terhitung dikalikan dengan seperfaktor pengenceran merupakan jumlah mikrobia/ml sisa susu (Fardiaz,1993).

\section{Proses pembuatan dipping bikang}

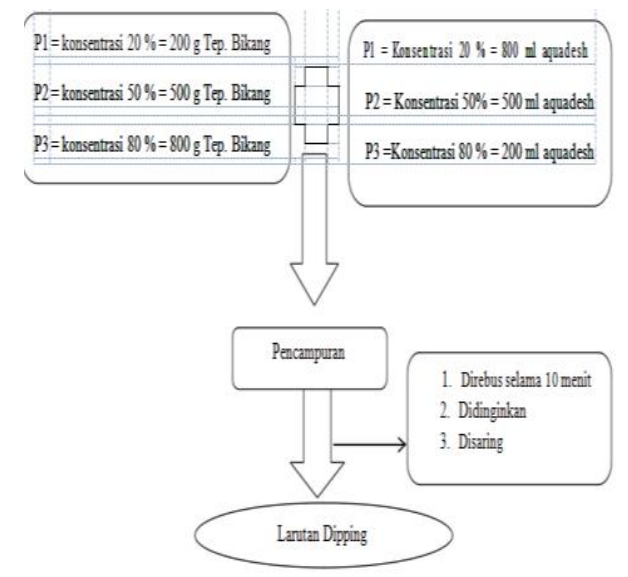

\section{Pehitungan Jumlah Bakteri dengan Uji Total Plate Count (TPC)}

Hasil penelitian menunjukkan bahwa persentase penurunan jumlah bakteri pada susu sapi (Tabel 5.1) tidak berbeda nyata $(P>0,05)$ untuk setiap kelompok perlakuan ( $P 0$, $\mathrm{P} 1, \mathrm{P} 2$ dan P3).

Tabel 1 Persentase (\%) Penurunan Jumlah Bakteri pada Susu Sapi.

\begin{tabular}{|c|c|c|c|c|c|}
\hline \multirow{2}{*}{$\begin{array}{l}\text { Perla } \\
\text { Kuan }\end{array}$} & \multicolumn{3}{|c|}{ Ulangan } & \multirow{2}{*}{ Total } & \multirow{2}{*}{ Rataan } \\
\hline & 1 & 2 & 3 & & \\
\hline PO & 16.27 & 36.30 & 25.72 & 78.28 & 19.57 \\
\hline P1 & 8.26 & 44.04 & 51.55 & 103.85 & 25.96 \\
\hline P2 & 44.35 & 74.30 & 31.72 & 150.37 & 37.59 \\
\hline P3 & 39.45 & 100 & 29.30 & 168.75 & 42.19 \\
\hline Total & 108.33 & 254.64 & 138.28 & 501.25 & 125.31 \\
\hline
\end{tabular}

Keterangan : Tidak ada perbedaan nyata $(P>0,05)$

Hal ini membuktikan bahwa larutan dipping dengan ekstrak biji dan kulit anggur hitam memiliki efektivitas yang sama dengan dipping sintetik dalam menurunkan jumlah bakteri dalam susu sapi.

Karena adanya resveratol pada biji dan kulit anggur hitam. Resveratrol yang terdapat pada buah anggur dapat meningkatkan aliran darah pada otak, sehingga dapat mereduksi dan mencegah penyakit bekerja dengan menghambat senyawa benzopyrene, yaitu senyawa yang dapat menyebabkan kanker, serta menghambat pertumbuhan sel abnormal (Xia et al, 2010).

Resveratrol banyak terdapat pada bagian kulit dan biji anggur. Kulit anggur segar mempunyai kandungan resveratrol sebanyak $40 \mathrm{mg}$ perliter ekstrak. Biji dan kulit anggur apabila diekstrak selain mengandung resveratrol juga mengandung flavonoid, saponin dan polifenol. Flavonoid merupakan antioksidan ampuh yang bekerja sebagai antimikroba. Saponin memiliki efek menurunkan kadar gula darah. Polifenol juga merupakan antioksidan, pada buah, biji dan kulit anggur dikenal dengan nama resveratrol yang menghambat enzim yang dapat menstimulir pertumbuhan sel kanker serta membunuh bakteri. Komponen polifenol pada biji dan kulit anggur diantaranya antosianin, flavonoid, tannin, resveratrol dan asam fenolat (Xia et al, 2010).

Kandungan senyawa fenol paling banyak ditemukan pada kulit, stem, daun dan biji dari anggur. Senyawa fenol dipercaya dapat digunakan untuk membunuh bakteri (bakterisid) (Xia et al., 2010). Flavonoid 
merupakan komponen terbesar dalam senyawa fenol yang mempunyai struktur kimia C6-C3-C6.Flavonoid terdapat dalam semua bagian anggur diantaranya kulit, daging, daun dan bijinya. Flavonoid pada prinsipnya mempunyai kandungan (+) catechin,(-) epicatechindan polimer procyanidin (Mu, et al., 2013). Flavonoid bersifat antibakteri karena mampu berinteraksi dengan DNA bakteri yang menyebabkan terjadinya kerusakan permeabiliHHtas dinding sel bakteri, mikrosom dan lisosom (Setyohadi et al., 2010). Ekstrak etanol dari biji anggur hitam memiliki kemampuan sebagai antibakteri terhadap bakteri gram positif Staphylococcus aureus dengan zona hambatan sebesar $26 \mathrm{~mm}$ pada konsentrasi 0,5 mg. (Rathi and Swahnhey, 2013).

Antosianin merupakan kelompok flavonoid yang berperan sebagai pigmen yang memberikan warna ungu pada beberapa buah dan sayuran seperti anggur.Komponen ini bermanfaat sebagai antioksidan dan menginduksi 2-4 kali meningkatkan DNA fragmen (Indra, 2012). Tannin mempunyai sifat antimikroba (Indra, 2012). Tannin juga dapat merusak membran sel bakteri yang ditandai dengan kebocoran sel dan lisis sehingga menghambat pertumbuhan bakteri (Setyohadi et al.2010).

Pada Tabel 5.1, terlihat bahwa penurunan jumlah bakteri dari yang terbaik yaitu P3, P2, P1 dan terendah adalah P0 meskipun pada analisis statistik tidak terdapat perbedaan yang nyata. Hal ini karena pada P3 mengandung ektrak biji dan kulit anggur hitam yang paling tinggi yaitu $80 \%$ dibandingkan dengan P2 (50\%) dan pada P1 (20\%). Semakin tinggi ekstrak biji dan kulit anggur hitam maka semakin tinggi pula kandungan resveratrol sehingga mampu membunuh bakteri dengan maksimal.

Penggunaan antiseptik sintesis sebagai larutan dipping dapat menimbulkan residu dalam susu sehingga dapat menimbulkan residu pada susu sehingga bahaya bagi kesehatan konsumen apabila dikonsumsi terus menerus. Hal ini didukung oleh penelitian Galton (2004) dan Borucki et al., (2012) yang menyatakan bahwa penggunaan iodophor sebagai larutan teat dipping dapat menimbulkan residu pada susu. Pemanfaatan desinfektan kimia dirasa tidak aman karena residu kimia yang ikut masuk dalam air susu hasil pemerahan sebagai faktor penyebab cemaran air susu.

\section{Scor California Mastitis Test (CMT)}

Hasil penelitian menunjukkan bahwa persentase (\%) penurunan skor CMT pada kelompok perlakuan (P0, P1, P2 dan P3) menunjukkan hasil tidak berbeda nyata $(P>0,05)$ seperti pada Tabel 2.

\begin{tabular}{lrrrll}
\hline $\begin{array}{l}\text { Perla } \\
\text { kuan }\end{array}$ & \multicolumn{3}{c}{ Ulangan } & \multirow{2}{*}{ Total } & Rataan \\
\cline { 2 - 4 } & 1 & 2 & 3 & & \\
\hline P0 & 0.55 & 1.65 & 1.45 & 3.65 & 0.91 \\
P1 & 1.15 & 0.25 & 1.50 & 2.90 & 0.73 \\
P2 & 1.60 & 1.55 & 1.70 & 4.85 & 1.21 \\
P3 & 2.35 & 1.60 & 1.55 & 5.50 & 1.38 \\
Total & 5.65 & 5.05 & 6.20 & 16.90 & 4.23 \\
\hline
\end{tabular}

Keterangan : Tidak ada perbedaan nyata $(P>0,05)$

Hal ini membuktikan bahwa penggunaan ekstrak biji dan kulit anggur hitam sebagai larutan dipping memiliki kemampuan yang sama dengan dipping sintetik untuk menurunkan skor CMT. Penurunan skor CMT yang tertinggi adalah pada P3 yang mengandung ekstrak biji dan kulit anggur hitam yang lebih tinggi yaitu $80 \%$ dibanding P2 dan P1. Hal ini disebabkan karena kandungan resveratrol yang tinggi sehingga mampu membunuh bakteri pada susu sapi dengan maksimal.

Uji CMT digunakan sebagai langkah awal dalam mendeteksi mastitis subklinis pada sapi. CMT merupakan reaksi antar reagen yang mengandung arylsulfonate dengan DNA leukosit membentuk masa gel, sehingga kualitas aglutinasi atau konsistensi gel yang terjadi merupakan gambaran jumlah sel leukosit yang berada dalam susu, akibat respon tubuh terhadap adanya infeksi bakteri (Suyadi et al., 2008). Kegiata pasca pemerahan perlu dilakukan untuk mencegah bakteri masuk dalam putting yang dapat megakibatkan peradangan di dalam sel ambing. Menurut Swadayana et al., (2012), bahwa pencelupan putting atau dipping ke dalam larutan desinfektan digunakan untuk melapisi atau menutup saluran susu pada putting agar tidak terjadi kontaminasi bakteri dan udara sekitar yang dapat menyebabkan menurunnya kualitas susu dan terjadinya peradangan pada ambing. Dipping yang dilakukan dapat menurunkan jumlah bakteri dan peradangan. Hal ini didukung pada Tabel 5.2 bahwa semakin tinggi jumlah persentase penurunan jumlah susu maka semakin tinggi juga penurunan skor CMT. 


\section{KESIMPULAN DAN SARAN}

\section{Kesimpulan}

Penggunaan ekstrak biji dan kulit anggur hitam sebagai dipping pada kualitas air susu dapat menurunkan bakteri cemaran air susu dan mastitis sapi perah. Ekstrak biji dan kulit anggur hitam dapat digunakan sebagai alternatif dipping sintetik dan pengobatan mastitis sub klinis. Penurunan total bakteri air susu sebesar $42.19 \%$ pada perlakuan terbaik yaitu p3 dan nilai test mastitis sebesar 1.38.

\section{Saran}

Perlu adanya penelitian lebih lanjut dengan konsentrasi ekstrak biji dan kulit anggur hitam yang berbeda sampai memberikan pengaruh yang nyata.

\section{DAFTAR PUSTAKA}

Abrar, Mahdi. 2009. Peranan hemaglutinin Escherichia coli dalam proses adhesi. Jurnal Kedokteran Hewan. 3(1):194-198.

Abrar,Mahdi, I Wayan T.W, Bambang Pontjo P, Mirnawati S, dan Fachriyan H.P.2013. Peranan Hemaglutinin Staphylococcus aureus dalam proses adhesi sel epitel ambing sapi perah.

Adriani. 2010. Penggunaan somatic cell count (SCC), jumlah bakteri dan california mastitis test (CMT) untuk deteksi mastitis pada kambing. Jurnal IImiah IImu Peternakan, 8(5): 229-234.

Andriani, 2010. Penggunaan Somatik Cell Count (SCC), Jumlah Bakteri dan California Mastitis Test (CMT) untuk Deteksi Mastitis pada Kambing. Jurnal IImiah IImu-IImu Peternakan Februari, 2010, Vol. XIII, No. 5.

Anri, A. 2008. Manual on Mastitis Control. The Project for Improvement of Countermeasures on the Productive Diseases on dairy Cattle in Indonesia. Jica Indonesia Office, Jakarta.

Boerlin, P, P. Kuhnert, D. Hussy dan M. Schaellibaum. 2003. Methods for identification of staphylococcus aureus isolates in cases of bovine mastitis. J. of Clinical Microbiology. American Society for Microbiology. 41 (2): 767 - 769.

Borucki, S.I., R. Berthiaume., A. Robichaud dan P. Lacasse. 2012. Effects of iodine intake and teat dipping practices on milk iodine concentrations in dairy cows. Journal Dairy Science, 95: 213.220.

Cappucino, J. G. dan N. Sherman. 2005. Microbiology: A Laboratory Manual. 7th ed. Pearson Education Inc. USA. 101 102, 117, 164, 166, 189, 204, 409 - 416, 509 - 512. Garcia, A. 2004. Contagious vs. Environmental Mastitis. 31 Extension Extra Dairy Science. South Dakota State University. USA. 4028: 1 - 4.

Carter, G.R. dan Wise, D.J., 2004. Essentials of Bacteryology and Mycology. 6th. Ed, lowa State Press. Pp $193-195$

Eleonora, Dobrei A. Dobrei Alina, Kiss Erzsebet, Ciolac Valeria. 2014. Grape Pomace as Fertilizer. Journal of horticulture, forestry and Biotechnology Volume 18(2), 141-145, 2014.

[FAO] Food and Agriculture Organization. 2008. Manual Untuk Paramedis Kesehatan Hewan. Budi Tri Akoso, dkk, penerjemah; Retno Yuliastuti, Budi Tri Akoso, editor.Sleman (ID): PT. Tiara Wacana Yogya. Terjemahan dari: Manual for Animal Health Auxilliary Personnel, Ed ke-2.

Fardiaz,1993. Mikrobiologi Pangan I. PT. Gramedia Pustaka Utama. Jakarta.

Foley CR, Bath LD, Dickinson NF, Tucker AH. 1972. Dairy Cattle: Principles, Practices, Problems, Profits. Philadelphia: Lea \& Febiger.

Galton, D. M. 2004. Effect of an Automatic Postmilking Teat Dipping on New Intramammary Infections and lodine in Milk. Journal dairy Science, 69(1): 225231.

Gaman, 1992.llmu Pangan, Pengantar IImu Pangan, Nutrisi dan Mikrobiologi, Murdijati G, et al, penerjemah. Yogyakarta: Penerbit Gajah Mada University Press. Terjemahan dari: The Science of Food, An Introduction to Food Science, Nutrition and Microbiology.

Harmon, R.J. 1994. Mastitis and genetic evaluation for somatic cell count. J. Dairy Sci. 77 (7) : 1151- 1161.

Hidayat. A, dkk. 2002. Buku Petunjuk Teknologi Sapi Perah Si Indonesia : Kesehatan Pemerahan. Dairy Technologi Improvement Project. PT. Sonysugema Presindo. Bandung. 
Hidayat A, 2008. Buku Petunjuk Praktis untuk Peternak Sapi Perah tentang, Manajemen Kesehatan Pemerahan. Dinas Peternakan Propinsi Jawa Barat.

Holtenius, K., S. Agenäs, C. Delavaud dan Y. Chilliard. 2003. Effects of feeding intensity during the dry period: 2 . Metabolic and hormonal responses. J. Dairy Sci. 86:883-891.

Hurley, W.L. dan D. E. MORIN. 2000. Mastitis lesson A. Lactation Biology. ANSCI 308. http://classes aces.uiuc.edu/Ansci 308/. Diakses 25 Mei 2017.

Indra, 2012.Super Foods Sehat dan Bugar dengan Beragam Pangan Fungsional Sehari-hari.FlashBooks. Jogyakarta.

Jawetz, E., J. L. Melnick dan E. A. Adelberg. 2001. Medical Microbiology. 22nd edition. McGraw Hill Companies Inc. USA. 223 - 233, 317 - 326.

Jawelz et al. dalam Yuswari 2006.Kajian Cemaran Mikroba pada Susu Pasteurisasi Asal Pedagang Keliling di Wilayah Jakarta Selatan (tesis).Sekolah Pasca Sarjana Institut Pertanian Bogor.Bogor

Jones, G.M. 2009. Understanding The Basic of Mastitis. Virginia. Cooperative Extension. Publication 404-233.

Julianto, 2011.Mengapa Stroke Menyerang Usia Muda. Javalitera.Jogyakarta.

Lestari D. T., 2006, Laktasi Pada Sapi Perah Sebagai Lanjutan Proses Reproduksi, Fakultas Peternakan Universitas Padjajaran.

Mu J.-J.He, Q.-H. Pan, F. He, C.-Q. Duan et al, 2013. Tissue-specific Accumulation of Flavonoids in Grape Berries is Related to Transcriptional Expression of $\mathrm{VvF}$ ' $\mathrm{H}$ and $V v F 3$ '5 'H.Centre for Viticulture and Oenology, College of Food Science and Nutritional Engineering, China Agricultural University, Beijing 100083, S. Afr. J. Enol. Vitic., Vol. 35, No. $1,2014$.

Nurdin E. dan Mihrani, 2006, Pengaruh pemberian bunga matahari dan bioplus terhadap produksi susu dan efisiensi ransum sapi perah freis holland penderita mastitis, Jurnal Agrisistem 2 (2).

Nurwantoro dan Siregar, 1997. Mikrobiologi Pangan HewaniNabati.Kanisius. Yogyakarta.

Oktaviantris, 2007.Deteksi Bakteri Staphylococcus Aureus Pada Susu Bubuk Skim (Skim Milk Powder) Impor.IPB. Bogor.
Paulo,M. Oleastro, Eugenia Gallardo, J.A Queiroz and F. Domingues, 2011.Antimikrobial Properties of Resveratrol. Institute Nacional Saude. Lisboa. Portugal.

Petrussa, E, Braidot E, Zancani M, Peresson, C., Bertolini A., Patui, S., Dam, Vianello.2013, Plant FlavonoidsBiosynthesis, Transport and Involvement in Stress Responses, Int. J. Mol. Sci.14 : 14950-14973.

Prasetyanti. 2016. Efektifitas Daun Kersen (Muntinga calabura L.) dalam Menurunkan Jumlah Bakteri dalam Susu dan Peradangan Pada Ambing Sapi PerahJurnal Ilmu-Ilmu Peternakan Vol. XIX No.1 Mei 2016:10-16 elSSN: 2528 0805 pISSN: 14107791.

Rahayu, I.D. 2009. Kerugian ekonomi mastitis subklinis pada sapi perah. Fakutas Pertanian Jurusan Peternakan. Universitas Muhammadiyah Malang.

Roh C, Kang C, 2014. Production of Anti Cancer Agent Using Microbial Biotransformation.Moleculas. 19. 1668416692:doi:10.3390/moleculas191016684 . ISSN 1420-3049.

Salasia O.I.S., Wibowo H.M., Khusnan, 2005, Karakterisasi Fenotipe Isolat Staphylococcus aureus Dari Sampel Susu Sapi Perah Mastitis Subklinis, Bagian Patologi Klinik, Fakultas Kedokteran Hewan UGM, Jurnal Sain Veteriner. Vol. 23 No. 2, Yogyakarta.

Setiadi, 2009.Bertanam Anggur. Penebar Swadaya. Jakarta.

Setiawan, J., R.R.A. Maheswari, dan B.P. Purwanto. 2013. Sifat fisik dan kimia, jumlah sel somatik dan kualitas mikrobiologis susu kambing peranakan ettawa. Acta Veterinaria Indonesiana. 1(1):32-43.

Setyohadi, R., 2010.Uji Efektivitas Ekstrak Ethanol Biji Buah Anggur (Vitis vinifera) sebagai Antibakteri terhadap Streptococcus mutans secara In Vitro.Program Studi Pendidikan Dokter Gigi Fakultas Kedokteran Universitas. UB. Malang.

Siregar, Sori basya, M.S. 1990. Sapi Perah. Penebar Swadaya, Jakarta.

Subronto. 2003. IImu Penyakit Ternak I. Edisi Kedua. Gadjah Mada University Press. Yogyakarta.

Sudarwanto M. 1982. Penggunaan metode Aulendorfer Mastitis Probe (AMP) untuk 
mendiagnosa mastitis subklinik. Prosiding Pertemuan IImiah Ruminansia Besar, Pusat Penelitian dan Pengembangan Peternakan, Balai Penelitian dan Pengembangan, Departemen Pertanian; Bogor, 7-9 Desember 1982. Bogor: Puslitbang Peternakan, Balitbang Pertanian, Dep. Pertanian.

Sudarwanto M. 1999. Mastitis subklinis dan cara diagnosa.(Makalah) Institut Pertanian Bogor, Bogor.

Sudarwanto, M. 2009. Mastitis dan kerugian ekonomi yang disebabkannya. Makalah pada TOT JICA The 3rd. Oktober 2009, Cikole-Lembang, Bandung Barat.

Sukada, IM. 1996. Kejadian Mastitis Subklinis oleh Streptococcus agalacticae di Daerah Semplak Bogor dan Pengaruhnya Terhadap Kualitas Susu (Tesis). Bogor: Program Pascasarjana. Institut Pertanian Bogor.

Soewito, W., A.E.T.H. Wahyuni., W. S. Nugroho dan B. Sumiarto. 2013. Isolasi dan identifikasi bakteria mastitis klinis pada kambing peranakan ettawah. Jurnal Sain Veteriner, 31(1): 49- 54.

Suyadi, P., Surjowardojo, L dan Aulani'am. 2008. Ekspresi produksi susu pada sapi perah mastitis. Jurnal Ternak Tropika, 9(2): 1-11.

Swadayana A., P. Sambodho., dan C. Budiarti. 2012. Total bakteri dan $\mathrm{pH}$ susu akibat lama waktu dipping puting kambing peranakkan ettawa laktasi. Animal Agriculture Journal, 1(1): 12-21.

Swartz, H.A. 2006. Mastitis in The Ewe. http://www.case.ageworld.com/cAw.LUm ast.html. Diakses 4 Mei 2017

Todar, K. 2005. Staphylococcus.: http://www.textbookofbacteriologynet/sta ph.html. Diakses tanggal 6 Mei 2017.

Tolan, R. W. 2008. Staphylococcus aureus infection. http://www.emedicine. com /ped/topic2704.htm. Diakses 6 Mei 2017.

XiaEn Qin,Gui Fang Deng, Ya Jun Guo, Hua Bin Li, 2010. Biological Activities of Polyphenols from Grapes.International
Journal of Molecular Science 622-646. 2010; 11(2).

Wahyuni A.E.T.H., Wibawan I.W.T., Wibowo $\mathrm{M} . \mathrm{H}, 2005$, Karakterisasi hemaglutinin streptococcus agalactiae dan staphylococcus aureus penyebab mastitis subklinis pada sapi perah. Jurnal Sain Veteteriner Vol. 23 No. 2, Bagian Mikrobiologi FKH-UGM, Yogyakarta.

Wannet, W. J., E. Spalburg, M. O. Heck, N. Pluster, E. Tiemersma, and R.J. Willem. 2005. Emergence of virulent methicillinresistant staphylococcus aureus strains carrying panton-valentine leucocidin genes in the netherlands. J Clin Microbiol. p. 3341-3345.

Winata F, 2011. Hubungan Antara Penggunaan Metode Breed Dengan Uji Mastitis IPB-1 Untuk Diagnosa Mastitis Subklinis (Skripsi). Bogor: Fakultas Kedokteran Hewan IPB. Institut Pertanian Bogor.

Yuswari R. 2006. Kajian Cemaran Mikroba pada Susu Pasteurisasi Asal Pedagang Keliling di Wilayah Jakarta Selatan (tesis). Bogor. Sekolah Pasca Sarjana Institut Pertanian Bogor. 